\section{Baserc SciencePark Research, Organization \& Counseling \\ Global Journal of Foreign Language Teaching}

Volume 7, Issue 2, (2017) 86-90

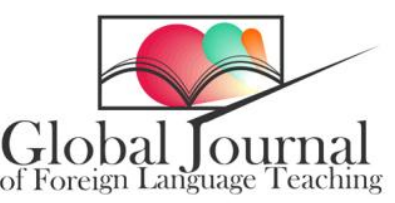

www.gjflt.eu

\title{
Foreign language listening anxiety among Turkish EFL learners
}

Rabia Borekci*, Imam Hatip High School, 10100 Balikesir, Turkey.

Fatih Yavuz, Necatibey Egitim Fakultesi, Balikesir University, 10100 Balikesir, Turkey.

\section{Suggested Citation:}

Borekci, R. \& Yavuz, F. (2017). Foreign language listening anxiety among Turkish EFL learners. Global Journal of Foreign Language Teaching. 7(2), 86-90.

Received from November 02, 2016; revised February 20, 2017; accepted April 23, 2017.

Selection and peer review under responsibility of Assoc. Prof. Dr. Ali Rahimi, Bangkok University, Thailand. 2017 SciencePark Research, Organization \& Counseling. All rights reserved.

\begin{abstract}
Among the skills, listening has a remarkable effect on learning a foreign language, and it is a keystone for communication. Foreign langua ge anxiety is an inte ma There a re various types of FLA and listening anxiety is one of them. The aim of this research is to identify the level of foreign language liste ning anxiety among Tur

school types and proficiency level. This research consists of 110 students from two different types of high school in the Turkish National Education System: vocational and public. Students were chosen randomly and the FLLA Scale was conducted; then the results were analysed with SPSS. According to the results, all these students experience FLLA and al though their acade mic proficiency level is quite different, there is no difference between the school types.
\end{abstract}

Keywords: Listening, listening comprehension, FLA, FLLA.

\footnotetext{
* ADDRESS FOR CORRESPONDENCE: Rabia, Borekci, Ima m Ha tip High School , 10100 Balikesir, Turkey
} E-mail address: rabia borekci@hotmail.com / Tel.: +905058775932 
Yurtbasi, M. (2017). The role of the secondarystress in teaching the English rhythm. Global Journal of Foreign Language Teaching. 7(3), 8690.

\section{Introduction}

For decades, foreign language learning has become crucial for several reasons such as better education and job opportunities, preferable life standards and higher incomes. Learners are expected to be competent in many fields in language learning, and listening is one of these skills, as it is a core term in the language acquisition process (Asher, 1969; James, 1982). In EFL classes, listening is an inseparable part of learning because it is the active dynamic process of attending, perceiving, interpreting, remembering and responding to the expressed verbal and non-verbal needs, concerns and information offered by other humans (Richards, 2008). Moreover, listening has a significant role in oral communication because learners are expected to be effective listeners from the very beginning of their learning process. The reason for this is that within most dassroom settings, listening serves as a primary channel for comprehension (Vandergrift, 1999) and separates the process from previous experiences, interest in the topic, etc. (Nichols, 1955). The course books are enriched by listening activities (Ur, 1984) and more and more listening activities are added to books. Namely, it is believed that listening comes before speaking because exposing enough listening activity is necessary for improving necessary speaking ability (Yavuz, 2011). The role of listening has broadened dramatically and its exponential effects have been tried to be clarified deeply. Although some theoreticians assume that listening is acquired naturally during sessions (Vogely, 1999), others think the opposite. Listening skill was one of the skills that intermediate learners experienced difficulty (Graham, 2002) in; to comprehend what is

clear sign that there is a problem which prevents learners from understanding the ongoing context.

\subsection{Foreign language listening anxiety}

Although there is much research on speaking, reading and writing anxiety, listening is considered less popular compared with other skills, so studies are limited (Ko, 2010). Listening anxiety was first defined by Elkhafaifi (2005), as a situation in which learners feel fear and nevousness in a foreign language because they are expected to understand what is said to be a part of the learning process. The source of the anxiety is clarified when learners experience difficulty in listening comprehension, which causes listening anxiety and has a negative effect on their performance (Ko, 2010). To evaluate these adverse effects, Kim (2005) developed a scale to define the level of anxiety learners experience while listening.

\section{Method}

, because FLLA may affect the whole language learning process adversely (Vogely, 1999). Course books contain many listening activities and comprehension is an effective way to be a part of the process. Moreover, in the Turkish National Education system, 9th grade students have started to have listening exams once or twice during the term. So listening anxiety that learners experience becomes crucial and the question this research is based on is whether there is a significant difference in FLLA among the students and also between the school types.

\section{Research questions}

The study aims to answer the following research questions: 
Yurtbasi, M. (2017). The role of the secondarystress in teaching the English rhythm. Global Journal of Foreign Language Teaching. 7(3), 8690.

1. What level of FLLA do learners have?

2. Is there a significant difference in FLLA between school types: vocational and general?

\subsection{Participants}

Foreign Language Listening Anxiety Scale was conducted on 29th December 2014 at Anadolu Imam Hatip High School (AIHL) and Muharrem Hasbi Anatolian High School (MHAL). 110 students were chosen randomly, 75 boys and 35 girls and they were in four classes. Two classes were chosen from MHAL and the others were chosen from AIHL. Their backgrounds were almost the same; they had all graduated from primary school and they had been learning English since the 4th grade and the students are exposed to the same activities based on the same curriculum. They also learn another foreign language. The difference between the schools is their type, which means that students had different results from the general exam and, depending on their results, they were accepted from these schools. MHAL is the only Anatolian high school, whereas AlHL is also a vocational school. Before this scale is conducted, the listening comprehension activities were regularly applied based on curriculum and they had at least one listening exam.

\subsection{Instrumentation}

The Foreign Language Listening Anxiety Scale developed by Kim (2005) was administered to foreign language learners. The scale consists of 33

one point and strongly agree is accepted as five points. The reliability of the scale is 0.93 (Kim, 2005). To provide better understanding the scale was translated into Turkish. The back translation technique was applied for FLLAS items. First, the researcher translated the scale into Turkish and then FLLAS items were translated back into English by anoth er

\subsection{Procedure}

The students were asked to complete the FLLAS. They were assured of anonymity and that participation in the study was voluntary. The aim of the research to gain an extensive understanding of FLLA was explained to learners and it was used to provide better insight into the level of the

between school types.

\section{Data Analysis}

Learners answered the questions in the FLLAS. The results were analysed with SPSS to obtain the mean, frequencies and standard deviations. To identify the difference between the groups, first, whether the total scores were normally distributed or not were checked and then independent samples $t$-test was applied.

\section{Results}

The Cronbach alpha of this questionnaire was 0.736 . The sum score which consists of the total of the test scores and the total of test items is normal $(P=0.641 ; p>0.05)$. The variances of sum were homogeneous. The variance of test item scores and sum is also homogeneous. As a result of these normal distributions independent samples t-test was used.

1. What level of FLLA do learners have?

The mean of all the points sum is 92 and the expected average score is 99 . The results show the -point 
Yurtbasi, M. (2017). The role of the secondarystress in tea ching the English rhythm. Global Journal of Foreign Language Teaching. 7(3), 8690.

Likert scale ranging from strongly disagree to strongly agree. The possible scores on the FLLAS range from

level was $92.10(s d=19.28)$ and 
Yurtbasi, M. (2017). The role of the secondarystress in teaching the English rhythm. Global Journal of Foreign Language Teaching. 7(3), 8690.

\section{References}

Asher, J. J. (1969). The total physical response approach to second language learning. The Modern Language Journal, 53(1), 317.

Cheng, J. C. (2005). The relationship to foreign language anxiety of oral performance achievement, teacher characteristics and in-class activities (Unpublished Master Thesis). Ming Chuan University, Taipei, Taiwan.

Elkhafaifi, H. (2005). Listening comprehension and anxiety in the Arabic language classroom. The Modern Language Journal, 89(2), 206220.

James, C. J. (1982). Are you listening? The practical components of Iistening comprehension. American Council on the Tea ching of Foreign Languages, 2527.

Kim, J. (2005). The reliability and validity of a foreign language listening anxiety scale. Korean Journal of English Language and Linguistics, 5(2), 213235.

Ko, Y. A. (2010). The effects of pedagogical agents on listening anxiety and listening comprehension in English as a foreign Language context (Unpublished Doctoral Dissertation). Utah State University, Logan, USA.

Nichols, R. G. (1955). Ten components of effective listening. Education, 75, 292302.

ing comprehension strategies in second language acquisition. Applied Linguistics, 10(4), 418437.

Richards, J. C. (2005). Second language listening: Theory and practice. Cambridge, UK: Cambridge University.

Rubin, J. (2011). A review of second language listening comprehension research. The modern Journal, 78, 199221.

Ur, P. (1984). Tea ching listening comprehension. Cambridge, UK: Cambridge University.

Vandergrift, L. (1992). The comprehension strategies of second language (French) listen ers (Unpublished Doctoral dissertation). University of Al berta, Edmonton, Canada.

Vogely, A. (1999). Addressing listening comprehension anxiety. In D. J. Young (Ed.), Affect in foreign language and second language learning. New York, NY: McGraw Hill.

Yavuz, F. (2011). The strategies and tactics the EFL students use in listening skills. Balikesir, Turkey: Social Sciences Institute, Balikesir University. 